\title{
善用民间传统体育游戏 促进幼儿健康发展
}

张玲

江苏省盐城市尚庄中心幼儿园

DOI:10.32629/jief.v2i11.2509

[摘 要] 随着信息技术的发展, 现代幼儿的游戏也逐渐转变为现代化的游戏, 但是作为文化的传承, 民间传统体育游戏是历史的沉淀, 是生 活经验的总结，在幼儿教育中发挥着现代游戏所不可替代的作用，所以在幼儿教育中要善用民间传统体育游戏来促进幼儿健康发展。

[关键词] 民间传统体育游戏; 幼儿; 健康发展

中图分类号：G613 文献标识码：A

《纲要》中指出, 幼儿的活动内容要贴近他们的生活, 以他们的情感 体验为主。所以就要求幼儿教师在关注现代游戏的同时也要挖掘民间传 统体育游戏, 发挥它的特性, 更好地达到教育幼儿的目的。

\section{1 民间传统体育游戏的特点}

民间传统体育游戏作为劳动人民几千年来的智慧结晶, 与现代游戏 相比有鲜明的特点。首先, 可操作性行强。民间传统体育游戏操作都比 较简单, 所需要的材料也容易获得, 比较符合当地的生活习惯, 其中很 多游戏只要有一个场地就能进行。其次, 规则简单明了。幼儿思维心智 还不成熟, 对于复杂的规则理解比较困难, 而民间传统体育游戏的规则 因为是从生活中总结出来的, 非常清晰简单, 符合幼儿的身心发展特点。 最后, 趣味性强。民间传统体育游戏是文化的传承, 是经过很多历史检 验过的, 所以留下来的都是深受广大人民群众喜爱的, 趣味性极强。

\section{2 将民间传统体育游戏融入幼儿教育的意义}

幼儿正处于活泼好动, 对新鲜事物充满浓厚兴趣的阶段, 而民间传 统体育游戏刚好能满足幼儿的这些需求, 并且在幼儿教育中运用民间传 统体育游戏还可以帮助增强体质, 了解传统文化, 感知生活经验。

\section{1 民间传统体育游戏能够激发幼儿运动的热情}

现在的幼儿动画片和游戏设计都比较精美, 色彩鲜艳, 形式多样, 能够吸引幼儿长时间进行观看和操作, 有的幼儿甚至沉迷于此, 而户外 的体育锻炼时间也越来越少。《规程》中明确规定幼儿每天必须有一定时 间的体育锻炼时间, 而如果我们的体育锻炼不能充满趣味性就不能让幼 儿真正投入到其中。民间传统体育游戏就很好地解决了这个问题, 它的 丰富性、趣味性及简单性能够让幼儿充分理解游戏规则, 进行多样的游 戏体验, 能够激发幼儿段炼的热情, 主动参与到各种游戏活动中去。

2.2 民间传统体育游戏能够培养幼儿团结合作的意识

由于现在的幼儿大部分都是独生子女, 在家里很少有机会和别的同 伴一起合作游戏, 在学校的集体生活就显得弥足珍贵。而民间传统体育 游戏都是需要相互合作来完成的, 幼儿在进行这些游戏活动的时候就能 够增加机会来互相协作, 真正体会到团结就是力量, 能够培养幼儿之间 的团结合作意识。

\section{3 如何更好地开展民间传统体育游戏}

民间传统体育游戏虽然简单有趣, 可操作性强, 但是幼儿是发展的 个体, 幼儿教师不能单纯地将传统游戏照搬到幼儿教育中, 而是要根据 幼儿的情况来选择游戏, 创新游戏。

3.1 根据幼儿特点优选游戏

每个年龄段的幼儿都有自身的特点, 所以一个游戏并不能全园适用, 要根据幼儿的特点来选择不同的民间传统体育游戏。首先, 要根据幼儿 的能力培养目标来有针对性地选择游戏。比如, 如果在进行幼儿数学意
识培养的同时来采取 “跳房子” 的游戏选择。在幼儿需要进行跳跃能力 培养的时候, 可以采用 “跳绳” 等游戏选择。其次, 要根据幼儿的身体 条件来进行选择游戏。小班的幼儿对游戏方式要求格外简单, 就可以采 取 “老鹰抓小鸡” 这种游戏。大班幼儿对游戏方式更讲究丰富性和自我 表达, 就可以采取 “丢手绢” 这种游戏。

3.2 根据幼儿发展创编游戏

每个地区都有自身的地方文化, 每个幼儿园也有自己不同的环境和 资源, 所以幼儿教师还应该根据自身的条件来对民间传统体育游戏进行 创编。第一, 结合发展特点来进行创新。比如《跳皮筋》里面, 经常用 的歌谣都是以前年代很久远的, 可以适当加入新时代的道德规范来进行 重新填词。第二, 观察幼儿兴趣来进行创新。民间传统体育游戏使用于 普通大众, 所以有的就需要教师根据幼儿的特性来进行改编。比如幼儿 现在喜爱的卡通形象可以加入到游戏中, 以此增加幼儿的情境感, 能更 好地将兴趣融入到游戏中。

\section{3 家园合作促进游戏开展}

现在的幼儿家长大部分都比较忙, 很少有时间能够陪伴幼儿, 闲暇 时间也更愿意做些自己愿意做的事, 缺少了与幼儿之间直接的情感沟通 机会。而民间传统体育游戏作为父辈传承下来的文化, 家长们也是从小 玩到大的, 所以对于他们来说也是童年的一段美好回忆。幼儿教师要充 分利用这一点, 将民间传统体育游戏融入到家园合作当中的一部分来, 让家长也有兴趣参与其中, 并且能够和孩子们共同游戏, 找到感情的共 鸣。比如, 可以让家长和幼儿一起收集感兴趣的民间传统体育游戏的方 式, 教师将这些游戏进行整理总结, 进行适当的改编, 作为亲子活动的 内容, 让家长和孩子们在欢声笑语中共享游戏的快乐, 增进彼此之间的 感情。

\section{4 总结}

民间传统体育游戏是我们的文化瑰宝, 是能够陪伴一代又一代人成 长的智慧传承, 幼儿教师要善于发现其促进幼儿发展的闪光之处, 仔细 钻研能够与现代社会发展相结合之处, 用先进科学的理念来进行改良创 新, 培养幼儿对传统文化的喜爱, 实现传统文化的熏陶, 帮助他们在游 戏中茁壮成长。

\section{[参考文献]}

[1]柴君宜.幼儿教育与民间传统体育游戏的融合路径探究 [J].才 智,2020(04):169.

[2]张红霞.民间游戏在幼儿教育中的传承性和创新点 [ J]. 文教资 料,2020(06):216-217+183.

[3]李黎燕.让幼儿体验科学探究的魅力 [J].课程教材教学研究 (教育 研究),2020(Z3):76-78. 